\title{
Crop Residue Management for Sustainable Agriculture
}

\author{
Rakesh Maurya $^{1 *}$, Chandrabhan Bharti ${ }^{1}$, Thokchom Dorenchand Singh ${ }^{1}$ \\ and Vijay Pratap ${ }^{2}$
}

\author{
${ }^{1}$ SNRM, CPGS, CAU, Umiam, Meghalaya- 793 103, India \\ ${ }^{2}$ ICAR-Indian Agricultural Research Institute, New Delhi-110012, India
}

*Corresponding author

\section{A B S T R A C T}

\begin{abstract}
India is facing various challenges in agriculture sector for sustaining soil fertility and food grains production, besides environmental degradation and food security of the country in the event of ever increasing demands of food grains production with limited cultivable land. Cultivable land and maintaining its soil fertility are one of the major tasks which supports about $17.6 \%$ of its population and leads to fact that, our natural resources are under considerable strain. Food grains are a major source of energy and are thus are vital for food and nutritional security. Besides, technological advances and use of machinery for crop harvesting leave behind large quantities of crop residues, which is burnt by farmers as cheap and easiest method with misconception that, burning of crop residues enhances soil fertility and helps in control weeds, insects and pests. From various studies, it is concluded that burning of crop residues result in heavy loss of organic carbon as well as soil nutrients, emits large amount of submicron aerosols and trace gases like Carbon dioxide $\left(\mathrm{CO}_{2}\right)$, Sculpture dioxide $\left(\mathrm{SO}_{2}\right)$, Carbon mono-oxide $(\mathrm{CO})$ and smoke, thereby posing problem to environment and human health hazards. As per Ministry of New and Renewal Energy, about $500 \mathrm{Mt}$ of crop residues are generated annually in India, used as animal feeding, soil mulching, composting, uses in mushroom production etc. As such, crop residues have tremendous plant nutrients, however, a large quantity of the crop residues (about 93 Mt) is burnt on-farm and primarily to clear the field for sowing of the successive crop and farmer also burn due to shortage of labour farmer can't be able to manage the residues, so they simple burn it (NPMCR, 2019). Crop residues also act as an alternate host for many of the insect, pest and diseases(Cox et al., 2004).In view of above, efforts were made to collect the data and suggest various technical and policy options for crop residue management to prohibit crop residue burning, enhancing soil fertility besides prevention of environmental degradation. The major recommendations includes, incorporation of crop residue in to the soil, adoption suitable crop rotation as recommended by ICAR or in Soil Health Care provided to the farmers, promotion of alternate competitive methods of utilizing residues in Small Scale Industries for use of crop residue/rice straw in paper/board/panel and packing material and biomass power plants establishment in Public Private Partnership mode to ensure economic return to the farmers and sustaining soil fertility and food grains production, besides prevention of environmental degradation in the country.
\end{abstract}

\section{Introduction}

The growing demand for food in various countries has led to huge increase in food production around the world. Hence, agrobased activities represent profitable businesses for both developed as well as developing countries. The crowed of agricultural activities increases the amount of agro-products produced and this has been led to an overall increase in environmental pollution and waste generation. Large stretches of wasteland have been converted to arable lands due to developments in modern agro-technologies, water management systems and large-scale agrochemical deployment (Nagendran, 2011).

These measures have been resulted in global environmental pollution and increased complexity in the disposal of agricultural wasted. However, the national agencies are 
continuously developing policies and possible options to manage these wastes, which include their conversion to reusable resources.

Crop residues are parts of the plants and left in the field after crops have harvested and threshed. The recycling of crop residues has the advantage for converting the surplus residues into useful product for meeting nutrient for soil microorganism as well as succeeding crops. Crop residues are a source of organic carbon for soil microorganisms and also contribute to plant nutrients. In India still a surplus of $140 \mathrm{Mt}$ out of which $92 \mathrm{Mt}$ is burned each year (NPMCR, 2019).

Crop residues retention on the soil surface, resulted reduces run-off as well as soil erosion and can decrease soil evaporation and land preparation costs (Lal, 1989). In India there are 500-550million tones (Mt) of crop residues are produces annually (MNRE, 2009). Mostly farmer's remove wheat straw used for feeding for animals. However, management of the rice straw is a major challenge task because high silica content so poorly feed for the animals. Combine harvester leaves behind a swath of loose rice straw, which interfere the operations of the seed drill used for sowing of wheat. To avoid these problems farmers burns their crop residues (90-140 Mt annually). From the farmers' point of view, burning may be seen as the best management practices for disposing of crops residues. It is not only a cost-effective method but it acts as an effective practices incest pest control (Dobermann and Fairhurst, 2002). (Gadde et al., 2009) estimated that the burning of rice straw contributed $0.05 \%$ of the total amount of greenhouse gas emissions in India, which not only lead to loss of the huge amount of biomass, i.e. organic carbon, plant nutrients, but also cause adverse effect on soil properties chemical and biological physical as well as soil flora and fauna.
So there is a need to adopt a suitable ways and means to manage this valuable resource. Crop residues incorporation in soil to maintain and restore soil fertility (Pituello et al., 2016).

\section{Why we needed for crop residue management?}

Management of crop residue due to mostly Indian farmer burned their crop residues. Approximately $730 \mathrm{Mt}$ of biomass was burned annually in Asia and $18 \%$ of that is from India ( Street et al., 2003). Burning of crop residue create following problems.

\section{Loss of nutrients}

It is estimated generally crop residues of different contains $80 \%$ of Nitrogen (N), $25 \%$ of Phosphorus (P), 50\% of Sulphur (S) and $20 \%$ of Potassium (K). It is also estimating that burning of one tonne of crop residue account for loss of the nutrient $5.5 \mathrm{Kg}$ Nitrogen, $2.3 \mathrm{Kg}$ phosphorus, $25 \mathrm{Kg}$ potassium and $1.2 \mathrm{~kg}$ sulphur besides, complete loss of organic carbon and polluting atmosphere and increase greenhouse gas emission led to climate change. If the crop residues are incorporated or retained the soil itself, soil gets enriched above mention nutrient, particularly with organic carbon and also meets food for soil microorganism and plant nutrient.

\section{Impact on soil properties}

Heat from burning of residues elevates soil temperature causing death of beneficial soil organisms. Burning of the crop residues immediately increases the bicarbonate extractable $\mathrm{P}$ content, but there is not build up nutrients in the soil profile. Frequent residue burning leads to complete loss of microbial population, though the effect is temporary, as the microbes regenerate after a few days. 
Repeated burning in the field also reduces level of $\mathrm{N}$ the nutrient and $\mathrm{C}$ and potentially mineralizable $\mathrm{N}$ in the upper $(0-15 \mathrm{~cm})$ soil layer.

\section{Emission of greenhouse gases (GHG)}

Burning of residues emits a significant amount of Green House Gasses (GHGs). About $70 \%, 7 \%$ and $0.7 \%$ of $\mathrm{C}$ present in rice straw is emitted as carbon dioxide $\left(\mathrm{CO}_{2}\right)$, carbon monoxide $(\mathrm{CO})$ and methane $\left(\mathrm{CH}_{4}\right)$, respectively, while $2 \%$ of $\mathrm{N}$ in straw is emitted as nitrous oxide $\left(\mathrm{N}_{2} \mathrm{O}\right)$ upon burning. This lead to increase greenhouse gas emission.

\section{Why farmer burn their crop residues?}

The Ministry of Agriculture attributes the increase in the on-farm crop residues burning to the shortage of the human labor.Reported that $80 \%$ of the crop residues burning took place during the post-harvest period of AprilMay and November-December months. The reason behind this is attributed to the crop patterns used to ensure a higher economic return which leaves limited time between two consecutive crop cultivations. Some farmers even resort to a cycle of three crops a year with a short gap between harvesting and sowing of the next crop. Crop residues also act as an alternate host for many of the insect, pest and diseases (Cox et al., 2004).

\section{Crop residue - types}

\section{Field residues}

Field residues are those residues left in an agricultural field after the crop has been harvested. These residues include stalks and stubble, leaves and seed pods. The residue can be ploughed directly into the ground, or burned first. In contrast, no-till, strip-till or reduced tillage in agriculture practices are carried out to maximize crop residue cover. Good management of field residues can increase the efficiency of irrigation and control of soil erosion.

\section{Process residues}

Process residues are materials left after the crop have been processed into a usable resource. These residues include husks, seeds, bagasse, molasses and roots. They can be used as animal fodder and soil amendment, fertilizers and in manufacturing.

\section{Nutrient content in crop residues}

Crop residues are a potential source of plant nutrients and their beneficial effects on soil fertility and productivity can be harnessed by recycling them into the soil that on an average $30-35 \%$ of applied nitrogen and phosphorus and $70-80 \%$ of potassium accumulate in the crop residues of food crops. About $40 \%$ of N, $30-35 \%$ of $\mathrm{P}, 80-85 \%$ of $\mathrm{K}$, and $40-50 \%$ of the $S$ uptake by rice remains in the vegetative parts at maturity. Similarly, about $25-30 \%$ of $\mathrm{N}$ and $\mathrm{P}, 35-40 \%$ of $\mathrm{S}$, and $70-75 \%$ of $\mathrm{K}$ uptake is retained in wheat residue. Moreover, crop residues are the primary source of organic matter (as C constitutes about $40 \%$ of the total dry biomass) which is indispensable for sustaining agricultural ecosystems. However they depend upon the soil conditions, crop management, variety as well as season determine the nutrient concentration in crop residues (Table 1).

\section{Crop residue potential in India}

The Ministry of New and Renewable Energy, Govt. of India (2009) has estimated that about $500 \mathrm{Mt}$ of crop residues are generated every year. The generation of crop residues is highest in UP (60 Mt) followed by Punjab (51 $\mathrm{Mt}$ ) and Maharashtra (46 Mt). Among different crops, cereals generate maximum 
residues (352 Mt), followed by fibers (66Mt), oilseeds (29 Mt), pulses (13 Mt) and sugarcane $(12 \mathrm{Mt})$. The cereal crops contribute $70 \%$ while rice crop alone contributes $34 \%$ and wheat ranks second with $22 \%$ of the crop residues (Table 2).

\section{Challenges for management of crop residue}

Huge volume of crop residue.

Collection \& Storage.

Time window between harvesting and sowing of two(next)crops.

Utilization of crop residue.

Cost-effective mechanization, awareness and availability of appropriate machinery.

\section{Management of crop residues}

\section{Balling and removing the straw}

Surplus straw from agriculture may be used for a number of useful purposes such as livestock feed, fuel, building materials, livestock bedding, composting for mushroom cultivation mushroom production is one of the areas with great potential for exploitation of forest and agricultural residues (Gregori et al., 2007). Bedding for vegetables such as cucumber, melons etc. and mulching for orchards and other crops.

\section{Soil mulch}

Direct drilling in the surface mulched residues is a practice that leaves crop residues from a previous crop on the soil surface without any form of incorporation. Surface retention of residues helps to protecting the fertile soil surface against wind as well as water erosion. (Thorne et al., 2003). The large volume of residues remaining on the surface often leads to machinery failures, thus affecting sowing of seeds of the following crop. Farmers usually follow this practices where no- till or conservation tillage practices are prevalent. Surface retention of some or all of the residues may be the best option in many situations. It suppresses the weed growth (Bilalis et al., 2003). Residues decompose slowly on the soil surface, increasing the organic carbon and total nitrogen in the top 5$15 \mathrm{~cm}$ of the soil, while protecting the surface soil from erosion. Retention of crop residues on the soil surface increased the soil $\mathrm{NO}_{3}$ concentration by $46 \%$, nitrogen uptake by $29 \%$, and yield by $37 \%$ compared to burning. It maintains the soil temperature (Lenka et al., 2012). Retention, however, provides habitat. For both harmful as well as useful organisms in one hand, and on the other it provides $\mathrm{C}$ substrate for heterotrophic $\mathrm{N}$-fixation, increase microbial activity, soil $\mathrm{C}$ and $\mathrm{N}$, and reduce fertilizer $\mathrm{N}$ requirements for rice. The faster decomposition and release of nitrogen to the soil is possible if this is treated with urea and applied during field preparation.

\section{Crop residues incorporation}

Crop residues may be incorporated partially or completely in the soil depend upon methods of cultivation. Straw incorporation can increase crop yield (Yang et al., 2016) Ploughing is the most efficient residue incorporation method. Incorporation of rice residues before sowing of wheat compared to incorporation of wheat straw before rice planting is difficult due to low temperatures and the short day interval between rice harvest and wheat sowing. Unlike removal or burning of crop residues incorporation of residues increases SOM and soil nitrogen, phosphorus and potassium contents. In few studies, wheat yields were lower during the first one to three years of rice straw incorporation 30 days prior to wheat planting because of immobilization of soil nitrogen in presence of crop residues with wide $\mathrm{C} / \mathrm{N}$ ratio, but in the later years, straw incorporation did not affect wheat yields adversely. In contrast, rice straw incorporation gave significantly higher wheat yields of $3.5 \mathrm{t} \mathrm{ha}^{-1}$ as compared to the $2.91 \mathrm{t}$ 
ha $^{-1}$ with straw removal. Crop residues, which contain abundant organic carbon and mineral nutrients, are important sources of organic matter that can be returned to soil for nutrient recycling and for improving soil physical, chemical, and biological properties (Kumar and Goh, 2000).

The major disadvantage of incorporation of cereal straw is the immobilization of inorganic $\mathrm{N}$ and its adverse effect due to $\mathrm{N}$ deficiency. Incorporation of rice straw into the soil after its harvest leads to slow down the decomposition process and soil inorganic nitrate is immobilized, reducing the nitrogen uptake and yield of subsequent wheat crops by about $40 \%$ (Table 3 ).

Table.1 Nutrient content in crop residues

\begin{tabular}{|l|c|c|c|}
\hline \multirow{2}{*}{ Crop Residues } & \multicolumn{3}{|c|}{ Nutrient content (\%) } \\
\cline { 2 - 4 } & $\mathrm{N}$ & $\mathrm{P}_{2} \mathrm{O}_{5}$ & $\mathrm{~K}_{2} \mathrm{O}$ \\
\hline Rice & 0.61 & 0.18 & 1.38 \\
\hline Wheat & 0.48 & 0.16 & 1.18 \\
\hline Maize & 0.52 & 0.18 & 1.35 \\
\hline Sugarcane & 0.40 & 0.18 & 1.28 \\
\hline Pulses & 1.60 & 0.51 & 1.75 \\
\hline
\end{tabular}

(Source:- Reddy and Reddy., 2003)

Table.2 Crop residue potential in India crop wise

\begin{tabular}{|l|l|}
\hline Crops & Residues $($ Mt) \\
\hline Cereals & 352 \\
\hline Pulses & 13 \\
\hline Oilseeds & 29 \\
\hline Sugarcane & 12 \\
\hline Fibers & 66 \\
\hline
\end{tabular}

Source - The MNRE, Govt. of India (2009)

Table.3 State-wise (major states) crop residue generated, residue surplus and burned in India

\begin{tabular}{|l|c|c|c|}
\hline States & $\begin{array}{c}\text { Residue } \\
\text { generation (Mt) }\end{array}$ & $\begin{array}{c}\text { Residue surplus } \\
\text { (Mt) }\end{array}$ & Residue burned(Mt) \\
\hline Uttar Pradesh & 59.97 & 13.53 & 21.92 \\
\hline Punjab & 50.75 & 24.83 & 19.65 \\
\hline Maharashtra & 46.45 & 14.67 & 7.42 \\
\hline Andhra Pradesh & 43.89 & 6.96 & 2.73 \\
\hline Karnataka & 33.94 & 8.98 & 5.66 \\
\hline West Bengal & 35.93 & 4.29 & 4.96 \\
\hline
\end{tabular}

Source - The MNRE, Govt. of India (2009) 
Due to straw incorporation, wheat yield depression (mean of 10 years) decreases from $0.54 \mathrm{t} \mathrm{ha}^{-1}$ to $0.08 \mathrm{t} \mathrm{ha}^{-1}$ with the application of $\mathrm{N} @ 60$ and $180 \mathrm{~kg} \mathrm{ha}^{-1}$, respectively. The combined uses of rice or wheat straw and fertilizer can, however, increase the yield of rice and wheat in rice-wheat cropping systems.

Farmers often apprehend to optimum for incorporation of the rice residues before planting of wheat because of the fact that nitrogen is temporarily immobilized for the following wheat crop, reducing its productivity. Of course, proper nitrogenous fertilizer management practices can reduce nitrogen immobilization due to incorporation of crop residues into the soil. These practices included suitable method, time, and rate of nitrogen fertilizer application (i) placement of $\mathrm{N}$ fertilizer below the surface soil layer that is enriched with carbon after incorporation of crop residue (ii) application of nitrogenous fertilizer at a higher rate than the recommended rate, and iii) application of nitrogen $15-20 \mathrm{~kg} \mathrm{ha}^{-1}$ as starter dose with straw incorporation increases yields of wheat and rice as compared to either burning of straw or its incorporation into the soil (Singh et al., 2004).

The recycling of crop residues has the great potential to return a considerable amount of plant nutrients to the soil. The yield of crops stagnation consequently upon due to declining soil organic carbon is a major threat to this system. Therefore it is a great challenge to the agriculturists to manage crops residues effectively and efficiently for enhancing sequestration of carbon and maintaining the sustainability of production. Crop residues management practices are also important as machines are being increasingly used for harvesting of grains and this mechanical harvesting leaves huge amount of crop residues in the field. There are several options for management of crop residues: mulching, incorporation in the soil and surface retention etc. Every management options have its advantages as well as disadvantages. Now it is the location, soil and situation, which will govern the practice to be selected. Of course, intensive research is required to solve this problem of managing rice residues. Sometimes surface retention may be the best option for sustainable agriculture. For sowing/ planting of subsequent crops having rice residues, both stubbles and loose straw in the field needs to be managed, for that intensive investigation in different crops growing areas is required. In long term incorporation of crop residue increase the soil physical, chemical and biological properties. No tillage technology may be adopted which is fitted to the location and soil condition. Incorporation of crop residues in soil is the best option as well as ecofriendly management practices for sustainable agriculture.

\section{References}

Biederbeck, V. O., Campbell, C. A., Bowren, K. E., Skitzer, M. and Melver, R. N. (1980). Effect of Burning cereal straw on soil properties and gain yields in baskatchewan. Soil Sci. Soc. Amer. J., 44: 103-111.

Bilalis, D., Sidiras, N., Economou, G.andVakali, C. ( 2003). Effect of different levels of wheat straw soil surface coverage on weed flora in Viciafaba crops. J. Agron. Crop; 89: 233-241.

Cox, C. M., Garrett, K. A., Bowden, R. L., Fritz, A.K., Dendy, S. P., Heer, W. F. (2004). Cultivar mixtures for the simultaneous management of multiple diseases: tan spot and leaf rust of wheat. Phytopathology, 94: 961-969.

Dick, R., Rasmussen, P., Kerle, E. ( 1988). Influence of long-term residue management on soil enzyme activities inrelation to soil chemical properties of a wheat-fallow system. Biol. Fertile. Soils, 6:159-164.

Dobermann, A., and Fairhurst, T. H.,(2002). Rice straw management. Better Crops International, Special supplement publication: Rice Production., pp: 16.

Gadde, B., Menke, C., Wassman, R. (2009). Rice straw as are newable energy source in India, Thailand and the Philippines: Overall potential and limitations for energy contribution and greenhouse gas migration. 
Biomass and Bioenergy; 33:11.

Grifith, D.R., and Mannering. J.V. (2002). Moldenhauer, Conservation tillage in the Eastern Corn Belt. J. Soil Water Cons., 32: 20-28.

Gupta, R. K., Yadvinder-Singh, Ladha. J. K., Jagmohan-Singh, Bijay-Singh, GurpreetSingh, Pathak, H. (2007). Yield and phosphorus transformations in a rice-wheat system with crop residue and phosphorus management. Soil Sci. Soc. Am J., 71: 1500-1507.

Gregori, A., Svagelj, M., Pohleven, F. (2007). Cultivation techniques and medicinal properties of Pleurotus spp. Food Technol Biotechnol., 45(3): 236-247.

Kumar, K. and Goh, K. M. (2000). Crop residues and management practices: effects on soil quality, soil nitrogen dynamics, crop yield, and nitrogen recovery. Adv. Agron., 68, 197-319.

Lal, R. ( 1989). Conservation tillage for sustainable agriculture: tropics versus temperate environments. Adv. Agron; 42:85-197.

Lenka N. K., Dass A., Sudhishri S. andPatnaik U. S. (2012). Soil carbon sequestration and erosion control potential of hedgerows and grass filter strips in sloping agricultural lands of eastern India. Agriculture, Ecosystems and Environment; 158: 31-40.

MoA (2012). Ministry of Agriculture, Govt. of India. New Delhi. Pp. 2-16

MNRE (2009) Ministry of new and Renewable energy. (https://mnre.gov.in/filemanager/annual-report/2009-

2010/EN/index.htm.

Nagendran, R. Agricultural Waste and Pollution. Waste 2011, 341-355.

NPMCR. (2019). National Policy for Management of Crop Residue Available online:

http://agricoop.nic.in/sites/default/files/NP

MCR 1.pdf.

Ponnamperuma, F. N. (1984). Straw as a source of nutrients for wet-land rice. In: Banta, S. and Mendoza, CV (Eds.). Organic Matter and Rice. IRRI, Los Banos, Philippines, 117136.

Pituello, C., Polese, R., Morari, F., and Berti, A. (2016). Outcomes from a long-term study on crop residue effects on plantyield and nitrogen use efficiency in contrasting soils. Eur. J. Agron., 77, 179-187.

Singh, S., Ladha, J.K., Khind, C.S., Khera, T.S. and Bueno, C.S. (2004). Effects of residue decomposition on productivity and soil fertility in rice-wheat rotation. Soil Sci. Soc Am J 68:854-864.

Streets, D.G., Yarber, K.F., Woo, J.H.and Carmichael, G.R. (2000). An Inventory of gaseous and primary aerosolemissions in Asia in the Year. J. Geophys. Res., 108, 8809-8823.

Thorne, M. E. (2003). No-till spring cereal cropping systems reduce wind erosion susceptibility in the wheat/fallow region of the Pacific Northwest. Journal of Soil and Water Conservation, 58, 251-257.

Yang, H.S., Xu, M.M., Koide, R.T., Liu, Q., Dai, Y.J., Liu, L. and Bian, X.M. (2016). Effects of ditch-buried straw return on water percolation, nitrogen leaching and crop yields in a rice-wheat rotation system. J. Sci. Food Agric., 96, 1141-114.

Zhang, P., Chen, X., Wei, T., Yang, Z., Jia, Z., Yang, B., Han, Q., Ren, X. (2016). Effects of straw incorporation on the soil nutrient contents, enzyme activities, and crop yield in a semiarid region of China. Soil Tillage Res, 160: 65-72.

\section{How to cite this article:}

Rakesh Maurya, Chandrabhan Bharti, Thokchom Dorenchand Singh and Vijay Pratap. 2020. Crop Residue Management for Sustainable Agriculture. Int.J.Curr.Microbiol.App.Sci. 9(05): 3168-3174. doi: https://doi.org/10.20546/ijcmas.2020.905.376 